\title{
Microbial phytase supplementation for improving availability of plant phosphorus in the diet of the growing pigs
}

\author{
MATTI NÄSI \\ Department of Animal Husbandry, \\ University of Helsinki, 00710 Helsinki, Finland
}

\begin{abstract}
The effect of a phytase supplement produced by Aspergillus niger on phytinphosphorus availability for pigs on phytase deficient maize-soybean meal diets was measured in two digestibility and balance experiments involving twelve growing pigs. Apparent digestibility of $\mathrm{P}$ in diets without inorganic-P supplementation or with low addition $(0.18$ of total $\mathrm{P})$ was significantly lower than in the control diets $(0.16$ and 0.23 vs. $0.42 ; \mathrm{P}<0.01)$, respectively. Phytase supplementation improved $\mathrm{P}$ digestibility $(\mathrm{P}<0.01)$ such that plant-P digestibility $(0.40$ and 0.28$)$ rose to the same level as the control diet. $P$ retention was also increased significantly by phytase supplementation. Calcium digestibility and retention were higher in phytase treated diets. Due to its effect on phytate-P availability, phytase treatment of feedstuffs allows a greater proportion on the pig's $\mathrm{P}$ requirement to be met by $\mathrm{P}$ of plant origin.
\end{abstract}

Index words: phytase, phosphorus, minerals, digestibility, availability, pig.

\section{Introduction}

In cereals and vegetable protein sources half to three quarters of the phosphorus $(\mathrm{P})$ occurs organically bound with phytic acid in form of myoinositolphosphate, which is the major storage form of $\mathrm{P}$ in plant tissue. The availability of plant-phytate-P is lower for pigs than that of non-phytate-P in plants or inorganic $\mathrm{P}$ of mineral sources and is variable among different plant feeds as reviewed by CROMwell (1980, 1989) and Jongbloed (1987). In order for the pigs to utilize the phosphorus from phytate it must be hydrolysed by phytate-degrading enzymes to yield phosphates.
Moreover, phytic acid binds strongly to other essential dietary minerals, such as calcium, zinc, magnesium, iron and copper, reducing their availability in the digestive tract of monogastrics (ZHU et al. 1990).

Although, phytase activity occurs in microbes and microbial phytases can be produced biotechnically, there are no reports of improved plant $\mathrm{P}$ utilization by pigs receiving phytase supplements (SHURSON et al. 1983 JongBloed 1987). However, in broilers phytase supplementation of diets (KIISKINEN and Pirronen 1990) and in chicks the addi- 
tion of phytase producing organisms to the diet has resulted in a marked improvement in the utilization of phytate-P (NELSON et al. 1971). In pigs, similar attempts to supplement the diets with a dried yeast product have been unsuccessful (Cromwell et al. 1978).

The objective of this study was to evaluate the possibility of improving the usage of phosphorus from plant ingredients by a phytase supplement produced by Aspergillus niger with a new technology. A maize-soybean meal pig ration containing low naturally occurring phytase activity was chosen as the test diet. Attention was also paid to the reduction of the phosphorus content of pig excrement in order to avoid the accumulation of phosphates in soils.

\section{Materials and methods}

Two experiments were conducted with six castrated growing pigs, in which the effect of added microbial phytase on the availability of plant phosphorus (P) was measured using balance assay.

The experimental diets were composed of maize $(880 \mathrm{~g} / \mathrm{kg})$ and soybean meal $(120 \mathrm{~g} / \mathrm{kg})$ and the daily allowances were $2500-2700 \mathrm{~g}$. The control diets in both exps. were supplemented with dicalcium phosphate to give $6.5 \mathrm{~g} / \mathrm{kg}$ total phosphorus in the ration. In exp. 1, diets 2 and 3 were supplemented with $3.3 \mathrm{~g} / \mathrm{kg}$ of dicalcium phosphate to provide 0.50 of total $\mathrm{P}$ of the control diet mixture. In exp. 2 no inorganic P-supplementation was added to diets 2 and 3 (Table 2). In control diets, maize and soybean meal contributed 0.44 of the total supply of $\mathrm{P}$ and dicalcium phosphate provided 0.56 . Calcium was added in all of the rations to provide diets with a content of $0.80 \%$ total calcium. The trace elements and vitamins were supplemented according to Finnish recommendations (SALO et al. 1982) in all treatments.

Table 1. Chemical composition of the experimental feed ingredients ( $\mathrm{g} / \mathrm{kg} \mathrm{DM})$.

\begin{tabular}{|c|c|c|c|c|c|c|c|}
\hline & $\begin{array}{c}\text { Dry } \\
\text { matter }\end{array}$ & Ash & $\begin{array}{l}\text { Crude } \\
\text { protein }\end{array}$ & $\begin{array}{l}\text { Ether } \\
\text { extract }\end{array}$ & $\begin{array}{c}\text { Crude } \\
\text { carbo- } \\
\text { hydrates }\end{array}$ & $\begin{array}{l}\text { Phos- } \\
\text { phorus }\end{array}$ & $\begin{array}{c}\text { Phytic } \\
\text { acid }\end{array}$ \\
\hline \multicolumn{8}{|c|}{ Soybean meal } \\
\hline Exp. 1 & 868 & 65 & 502 & 36 & 398 & 7.87 & 4.33 \\
\hline Exp. 2 & 895 & 66 & 497 & 36 & 401 & 7.29 & 4.38 \\
\hline \multicolumn{8}{|l|}{ Maize } \\
\hline Exp. 1 & 860 & 13 & 98 & 50 & 839 & 2.80 & 2.82 \\
\hline Exp. 2 & 878 & 15 & 95 & 58 & 832 & 2.78 & 3.04 \\
\hline \multicolumn{8}{|l|}{$\begin{array}{l}\text { Dicalcium } \\
\text { phosphate }\end{array}$} \\
\hline Exp. 1 & 802 & 782 & & & & 185.44 & \\
\hline Exp. 2 & 983 & 853 & & & & 166.27 & \\
\hline
\end{tabular}

Table 2. Feed intake of pigs. (Exp. 1, Exp. 2), (g DM/d).

\begin{tabular}{|c|c|c|c|c|c|c|}
\hline \multirow{2}{*}{$\begin{array}{l}\text { Experiment } \\
\text { Treatment }\end{array}$} & \multicolumn{3}{|c|}{ I } & \multicolumn{3}{|c|}{ II } \\
\hline & 1 & 2 & 3 & 1 & 2 & 3 \\
\hline Maize & 1950 & 1954 & $195 \dot{5}$ & 1994 & 1921 & 1998 \\
\hline Soybean meal & 269 & 269 & 269 & 277 & 267 & 278 \\
\hline Calcium carbonate & 9 & 41 & 41 & 13 & 47 & 49 \\
\hline Dicalcium phosphate & 52 & 9 & 9 & 57 & - & - \\
\hline Sodium chloride & 5 & 5 & 5 & 5 & 5 & 5 \\
\hline Trace element prem. & 15 & 15 & 15 & 16 & 16 & 16 \\
\hline Phytase supplement & - & - & 11 & - & - & 2.3 \\
\hline
\end{tabular}


The phytase product Finase-F (produced by Alko Ltd., Rajamäki, Finland) was used in both experiments. The level of supplementation in diet 3 in Exp. 1 was $100000 \mathrm{Pu} / \mathrm{kg}$ feed (1 $\mathrm{Pu}$ is the amount of enzyme that liberates $1 \mathrm{nmol}$ of inorganic phosphorus from sodiumphytate in one minute, $37^{\circ} \mathrm{C}, \mathrm{pH} 5.0$ ) and $500000 \mathrm{Pu} / \mathrm{kg}$ in Exp. 2, respectively. The enzyme was added to the ration in liquid form just before feeding. Finase-F preparation is produced by Aspergillus niger var. and the phytase is acid and heat resistant over broad $\mathrm{pH}$ and temperature ranges $(\mathrm{pH} 2.0-6.0$ and up to $60^{\circ} \mathrm{C}$ ).

The experiment had a $3 \times 3$ replicated Latin square designs and the pigs had an average liveweight of 78 and $98 \mathrm{~kg}$ in exp. 1 and 2, respectively. Each period was comprised of 6 days of adjustment and 6 days of faeces and urine total collection. The chemical analyses of feeds and faeces were performed according to the official procedures. Phytic acid contents were analysed using the method of CAmire and Clydesdale (1982). Phosphorus was determined after dry ashing by the method of TAYSSKY and SHORR (1953) and minerals were measured on the diet ingredients, faeces and urine with a Varian Techtron AA1000 atomic-absorption spectrophotometer.

\section{Results and discussion}

Average daily dry matter intake of the pigs was $79 \mathrm{~g}$ in Exp. 1 and $75 \mathrm{~g}$ in Exp. 2 per $\mathrm{kg}$ $\mathrm{W}^{0.75}$. Daily phosphorus intakes of pigs receiving the control diet were $17.2 \mathrm{~g}$. Pigs on diets 2 and 3 in Exp. 1 consumed $9.3 \mathrm{~g} \mathrm{P} /$ day, and in Exp. 2 consumed $7.5 \mathrm{~g} /$ day (Table 2). Dicalcium phosphate contributed 0.56 of the total P supply in control diets and 0.18 of total $\mathrm{P}$ in diets 2 and 3 of Exp. 1. No supplemental phosphorus was added in Exp. 2 on diets 2 and 3; all of the P supply was of plant origin.

Organic matter digestibility was not different between the treatments in either experiment ( $P>0.05$, Table 3). Finase-F also contains some proteinase, amylase and pectinase activity, however, digestibility was not affected in this trial. The ash digestibility was improved significantly by phytase supplementation $(\mathrm{P}<0.01)$ in Exp. 2. and showed a similar tendency in Exp. 1. Nitrogen digestibility was significantly higher in Exp. 2. in pigs receiving diets without an inorganic phosphorus supplement $(\mathrm{P}<0.05)$. However, there was no effect on $\mathrm{N}$ balance (Table 4). A number of other investigations have pointed out that there is often strong binding between phytic acid and protein (ZHU 1990) but in this study

Table 3. Digestibilities of the nutrients in pigs on the experimental diets.

\begin{tabular}{|c|c|c|c|c|c|}
\hline & $\begin{array}{l}\text { Org. } \\
\text { matter }\end{array}$ & $\begin{array}{l}\text { Crude } \\
\text { prot. }\end{array}$ & $\begin{array}{l}\text { Ether } \\
\text { extr. }\end{array}$ & $\begin{array}{c}\text { Crude } \\
\text { carbo- } \\
\text { hydr. }\end{array}$ & Ash \\
\hline \multicolumn{6}{|l|}{ Experiment 1.} \\
\hline $\begin{array}{l}\text { Diet } 1 \\
\text { Diet } 2 \\
\text { Diet } 3\end{array}$ & $\begin{array}{l}0.911 \\
0.905 \\
0.907\end{array}$ & $\begin{array}{l}0.866 \\
0.856 \\
0.859\end{array}$ & $\begin{array}{l}0.734 \\
0.721 \\
0.726\end{array}$ & $\begin{array}{l}0.929 \\
0.924 \\
0.926\end{array}$ & $\begin{array}{l}0.486 \\
0.525 \\
0.548\end{array}$ \\
\hline $\begin{array}{l}\text { SEM } \\
\text { Statist. signif. }\end{array}$ & $\begin{array}{l}0.0036 \\
\text { NS }\end{array}$ & $\begin{array}{l}0.0046 \\
\text { NS }\end{array}$ & $\begin{array}{l}0.0071 \\
\text { NS }\end{array}$ & $\begin{array}{l}0.0037 \\
\text { NS }\end{array}$ & $\begin{array}{l}0.0239 \\
\text { NS }\end{array}$ \\
\hline \multicolumn{6}{|l|}{ Experiment 2.} \\
\hline $\begin{array}{l}\text { Diet } 1 \\
\text { Diet } 2 \\
\text { Diet } 3\end{array}$ & $\begin{array}{l}0.903 \\
0.919 \\
0.914\end{array}$ & $\begin{array}{l}0.851^{\mathrm{a}} \\
0.884^{\mathrm{b}} \\
0.873^{\mathrm{ab}}\end{array}$ & $\begin{array}{l}0.809 \\
0.833 \\
0.817\end{array}$ & $\begin{array}{l}0.916 \\
0.931 \\
0.928\end{array}$ & $\begin{array}{l}0.524^{\mathrm{a}} \\
0.560^{\mathrm{a}} \\
0.642^{\mathrm{b}}\end{array}$ \\
\hline $\begin{array}{l}\text { SEM } \\
\text { Statist. signif. }\end{array}$ & $\begin{array}{l}0.0043 \\
\text { NS }\end{array}$ & $\begin{array}{l}0.0065 \\
*\end{array}$ & $\begin{array}{l}0.0082 \\
\text { NS }\end{array}$ & $\begin{array}{l}0.0038 \\
\text { NS }\end{array}$ & $\begin{array}{l}0.017 \\
* *\end{array}$ \\
\hline
\end{tabular}

${ }^{a-b}: * P<0.05, * * P<0.01$ 
Table 4. Nitrogen balance and protein utilization.

Exp. 1.

\begin{tabular}{lccccc}
\hline Treatment & 1 & 2 & 3 & SEM & $\begin{array}{c}\text { Statist. } \\
\text { signif. }\end{array}$ \\
\hline $\mathrm{N}$ intake, g/d & $52.31^{\mathrm{a}}$ & $52.43^{\mathrm{a}}$ & $52.83^{\mathrm{b}}$ & 0.110 & $*$ \\
$\mathrm{~N}$ excretion in faeces & 7.00 & 7.53 & 7.47 & 0.236 & $\mathrm{NS}$ \\
$\mathrm{N}$ absorption, g/d & 45.31 & 44.90 & 45.35 & 0.312 & $\mathrm{NS}$ \\
$\mathrm{N}$ digestibility & 0.866 & 0.856 & 0.859 & 0.0046 & $\mathrm{NS}$ \\
$\mathrm{N}$ excretion in urine & 22.32 & 23.73 & 23.28 & 0.474 & $\mathrm{NS}$ \\
$\mathrm{N}$ retained, g/d & 22.99 & 21.17 & 22.07 & 0.461 & $\mathrm{NS}$ \\
$\quad$ of intake & $0.440^{\mathrm{a}}$ & $0.404^{\mathrm{b}}$ & $0.419 \mathrm{~b}$ & 0.0084 & $*$ \\
$\quad$ of absorption & 0.508 & 0.472 & 0.487 & 0.0097 & $\mathrm{NS}$ \\
g/kg W.75 & 0.790 & 0.731 & 0.770 & 0.015 & $\mathrm{NS}$ \\
Biological value & 0.601 & 0.567 & 0.581 & 0.0091 & $\mathrm{NS}$ \\
\hline
\end{tabular}

Exp. 2.

\begin{tabular}{|c|c|c|c|c|c|}
\hline Treatment & 1 & 2 & $3-5$ & SEM & $\begin{array}{l}\text { Statist. } \\
\text { signif. }\end{array}$ \\
\hline $\mathrm{N}$ intake, $\mathrm{g} / \mathrm{d}$ & 52.29 & 51.62 & 52.39 & 0.433 & NS \\
\hline $\mathrm{N}$ excretion in faeces & $7.76^{a}$ & $5.98^{b}$ & $6.66^{\mathrm{ab}}$ & 0.350 & $*$ \\
\hline $\mathrm{N}$ absorption, $\mathrm{g} / \mathrm{d}$ & $A 4.53$ & 45.63 & 45.73 & 0.323 & NS \\
\hline $\mathrm{N}$ digestibility & $0.851^{\mathrm{a}}$ & $0.884^{b}$ & $0.873^{\mathrm{ab}}$ & 0.0065 & $*$ \\
\hline $\mathrm{N}$ excretion in urine & 22.13 & 23.65 & 22.96 & 0.774 & NS \\
\hline $\mathrm{N}$ retained, $\mathrm{g} / \mathrm{d}$ & 22.40 & 21.98 & 22.77 & 0.673 & NS \\
\hline of intake & 0.428 & 0.428 & 0.435 & 0.0161 & NS \\
\hline of absorption & 0.504 & 0.483 & 0.498 & 0.0151 & NS \\
\hline $\mathrm{g} / \mathrm{kg} \mathrm{W}^{0.75}$ & 0.72 & 0.71 & 0.73 & 0.023 & NS \\
\hline Biological value & 0.603 & 0.581 & 0.596 & 0.0140 & NS \\
\hline
\end{tabular}

$a-b: * P<0.05$.

phytase treatment did not result any improvement in protein digestibility.

The apparent digestibility of $\mathrm{P}$ on the control diet averaged 0.42 in both trials and was significantly higher $(\mathrm{P}<0.05,0.01)$ than that of the diets without inorganic phosphorus supplementation (Exp. 2) or with low (0.18 contribution of total P) phosphate addition in Exp. 1 (Table 5). Phytase supplementation of the diet resulted a significant improvement in phosphorus digestibility $(\mathrm{P}<0.01)$ compared with that of the unsupplemented diet. Phytase improved plant-P digestibility such that it rose to the same level as the inorganic-P supplemented diet (Exp. 2). Also in Exp. 1 phytase enhanced apparent digestibility of $\mathrm{P}$ by five percentage units $(\mathrm{P}>0.05)$. The apparent digestibility assay of the $\mathrm{P}$ in the total diet, however, poses some difficulties in the interpretation of the results, particularly when $\mathrm{P}$ supplies are different as in present study.
Endogenous P secretions also complicate the measurement (JoNGBLOED 1987), who reported the value of $5 \mathrm{mg} / \mathrm{kg}$ metabolic weight excreted in faeces. An approximation of these daily P-losses in pig is $1.5-2.5 \mathrm{~g} / 100 \mathrm{~kg}$ body weight (ARC 1981).

Similar low apparent $\mathrm{P}$ digestibilities as in present maize-soybean meal diets have been reported in cereals or cereal-based diets containing no supplemental P (PIERCE et al. 1977, CAlvert et al. 1978, JongBloed 1987, OKSBJERG 1988). Phosphorus from phytate cannot be absorbed in its original form by pigs and so it must first be released by hydrolysis by phytate-degrading enzymes to yield inositol and phosphoric acid. Almost all vegetable feed ingredients poses phytase, although with different levels of activity (NELSON 1969). Maize has been reported to have very low contents of natural phytase (CALVERT et al. 1978, Pointillart et al. 1984, 1988, OKSBJERK 
Table 5. Phosphorus excretion, apparent absorption and retention in pigs.

Exp. 1.

\begin{tabular}{llllll}
\hline Treatment & 1 & 2 & 3 & SEM & $\begin{array}{r}\text { Statist. } \\
\text { signif. }\end{array}$ \\
\hline P intake, g/d & $17.16^{\mathrm{a}}$ & $9.30^{\mathrm{b}}$ & $9.34^{\mathrm{a}}$ & 0.107 & $* * *$ \\
P excretion in faeces & $9.69^{\mathrm{a}}$ & $7.12^{\mathrm{b}}$ & $6.71^{\mathrm{b}}$ & 0.197 & $* * *$ \\
P absorption, g/d & $7.47^{\mathrm{a}}$ & $2.18^{\mathrm{b}}$ & $2.63^{\mathrm{b}}$ & 0.207 & $* * *$ \\
P digestibility & $0.43^{\mathrm{a}}$ & $0.235^{\mathrm{b}}$ & $0.284^{\mathrm{ab}}$ & 0.0216 & $* * *$ \\
P excretion in urine & $5.59^{\mathrm{a}}$ & $0.38^{\mathrm{b}}$ & $0.20^{\mathrm{b}}$ & 0.317 & $* *$ \\
P retained, g/d & 2.23 & 1.79 & 2.43 & 0.380 & NS \\
$\quad$ of intake & 0.128 & 0.193 & 0.261 & 0.0312 & NS \\
$\quad$ of absorption & $0.312^{\mathrm{c}}$ & $0.828^{\mathrm{ad}}$ & $0.927^{\mathrm{bd}}$ & 0.0315 & $* *$ \\
$\mathrm{~g} / \mathrm{kg}$ W & 0.75 & $0.07^{\mathrm{a}}$ & $0.09^{\mathrm{a}}$ & 0.063 & NS \\
\hline
\end{tabular}

Exp. 2.

\begin{tabular}{|c|c|c|c|c|c|}
\hline Treatment & 1 & 2 & 3 & SEM & $\begin{array}{l}\text { Statist. } \\
\text { signif. }\end{array}$ \\
\hline$P$ intake, $g / d$ & $17.19^{\mathrm{a}}$ & $7.54^{b}$ & $7.65^{b}$ & 0.103 & $* * *$ \\
\hline$P$ excretion in faeces & $10.07^{a}$ & $6.33^{b}$ & $4.59^{c}$ & 0.293 & $* *$ \\
\hline P absorption, g/d & $7.11^{\mathrm{a}}$ & $1.21^{\mathrm{b}}$ & $3.06^{c}$ & 0.276 & $* * *$ \\
\hline $\mathbf{P}$ digestibility & $0.414^{a}$ & $0.162^{b}$ & $0.400^{\mathrm{a}}$ & 0.0271 & $* * *$ \\
\hline $\mathrm{P}$ excretion in urine & $3.37^{\mathrm{a}}$ & $0.16^{\mathrm{b}}$ & $0.06^{\mathrm{b}}$ & 0.094 & $* * *$ \\
\hline$P$ retained, $g / d$ & $3.72^{a}$ & $1.04^{b}$ & $3.00^{\mathrm{a}}$ & 0.212 & $* * *$ \\
\hline of intake & $0.217^{\mathrm{a}}$ & $0.139^{\mathrm{a}}$ & $0.392^{b}$ & 0.0206 & $* * *$ \\
\hline of absorption & $0.523^{a}$ & $0.887^{b}$ & $0.979^{b}$ & 0.0283 & $* * *$ \\
\hline $\mathrm{g} / \mathrm{kg} \mathrm{W}^{0.75}$ & $0.12^{\mathrm{a}}$ & $0.03^{\mathrm{b}}$ & $0.10^{\mathrm{a}}$ & 0.007 & $* * *$ \\
\hline
\end{tabular}

a-c: * $\mathrm{P}<0.05,{ }^{* *} \mathrm{P}<0.001,{ }^{* * *} \mathrm{P}<0.001$

1988), which is why this diet was chosen to test microbial phytase supplementation even though maize is not used in pig feeding in Finland. In contrast to this the seed coats of wheat and barley have relatively high phytase activity. The optimum $\mathrm{pH}$ for plant phytase is about $4.0-6.0$ as reviewed by IRWING (1980) therefore plant phytase probably does not survive the acid conditions of the stomach.

$\mathrm{P}$ digestibility in maize-based diets has been improved by treatments other than microbial phytase supplementation. FrAPE et al. (1979) and BAgHeri and Gueguen (1985) have shown that absorption coefficients of phosphorus in a maize SBM diet without added $\mathrm{P}$ were increased from 0.36 to 0.48 by introduction of $200 \mathrm{~g} / \mathrm{kg}$ wheat bran into the diet. Similarly, Fourdin et al. (1988) reported that rye bran supplementation $(200 \mathrm{~g} / \mathrm{kg}) \mathrm{im}$ proved $\mathrm{P}$ retention $40-50 \%$ in pigs on low $\mathrm{P}$ maize diets. In high-moisture maize the $\mathrm{P}$ is 3 to 4 times more available than in dried grain (Boyd et al. 1983). The improvements with those treatments have been similar or better than that of the present study of microbial phytase supplementation.

Besides being present in the feedstuffs, phytases are produced by the microbes in the intestine and are also secreted by the intestinal tract of the pig. Intestinal alkaline phosphatase can hydrolyse some phytate (PoINTILLARD et al. 1984). However, it has been concluded that intestinal phytase does not seem to be of great significance for the hydrolysis of phytate (Pointillart et al. 1984). In the large intestine with its rich microbial flora phytate can be hydrolysed by bacterial phytases. However, the pig's absorption of phosphorus in the large intestine is very limited and no $\mathrm{P}$ or only a limited amount of $\mathrm{P}$ was absorbed beyond an ileal fistula (JORGENSEN et al. 1985). 
The retention of phosphorus was $0.13-$ 0.22 of $\mathrm{P}$ intake on the control diets and $0.14-0.19$ on diets without inorganic $\mathrm{P}$ supplementation. This low availability is in accordance with existing literature. Microbial phytase supplementation improved retention of phosphorus to the level of $0.26-0.39$ and the difference was significant $(\mathrm{P}<0.01)$ compared with the untreated non $\mathrm{P}$-supplemented diet. Retention of the absorbed P was very high $(0.93-0.98)$ in diets supplemented with phytase and was 0.10 higher relative to the untreated diets $(\mathrm{P}<0.05$ in the first Exp.). Some low-molecular weight myoinositol phosphates were probably absorbed but could not be utilized by the pig.

The retention of $\mathrm{P}$ in Exp. 1 was considerable lower compared to Exp. 2, but the reason for this remains uncertain. Average daily gain of pigs in Exp. 1 was $729 \mathrm{~g}$, while it was $854 \mathrm{~g}$ in Exp. 2. The pigs on low-P phytase unsupplemented diet had the lowest gains as well as the lowest P-retention. The effect of phytase supplementation was different between the two experiments due to the application level, which was five-fold higher in the second trial. JongBloed (1987) found that in slaughter pigs on average $4.9 \mathrm{~g} \mathrm{P} / \mathrm{kg}$ live weight was retained. The phosphorus availability in most inorganic phosphate supplements approaches 0.7 to 1.0 (CROMWELL 1989, Jongbloed 1987, Den Hartog et al. 1988).

Calcium digestibility was improved by the phytase supplementation and retained $\mathrm{Ca}$ was significantly $(\mathrm{P}<0.01)$ higher compared to the untreated diet (Table 6). When the intake of $\mathrm{Ca}$ is adequate but that of $\mathrm{P}$ inadequate, the retention of Ca falls (JongBloEd 1987). In the present study the calculated $\mathrm{Ca} / \mathrm{P}$ ratios were 0.93 and 2.07 for control and experimental groups, respectively, while the optimum $\mathrm{Ca} / \mathrm{P}$ ratio is from 1.2 to 1.3 : 1 (ARC 1981). Digestibility of magnesium also tended to be increased by the phytase treatment but retention was not affected. Iron supply was higher in the control diet due to the high content of iron in dicalciumphosphate. Fe digestibility was not different between diets but retention in the control diet was significantly higher. Copper and zinc digestibility and retention were higher in diets without phosphate addition but phytase supplementation did not affect any difference in utilization. Phytic acid readily forms complexes with several essential minerals such as calcium, iron, zinc and manganese and also protein impairing their utilization by the animal (NeLson et al. 1971).

There are no previous reports of successful addition of microbial phytase to pig diets. However, many of the fungi, bacteria and yeasts are good sources of phytase. Attempts to improve phytate utilization in pigs by including a dried yeast product in the diet have been unsuccessful (CROMwell et al. 1978). In contrast, several studies with chicks have demonstrated that the addition of phytaseproducing organisms to the diet can result in a marked improvement in the utilization of phytate phosphorus (NELSON et al. 1971, Cromwell 1980). Shurson et al. (1983) was not able to improve phytate utilization in pigs by including a yeast phytase in the diet. It is possible that the additions of phytase have been insufficient or that the phytase used has not been resistant to the low $\mathrm{pH}$ in the stomach of the pig. In this study 100000 $\mathrm{Pu} / \mathrm{kg}$ was not sufficient because increasing phytase activity gave a greater response in the Exp. 2. The Finase-F preparation is thermotolerant and acid-resistant to a $\mathrm{pH}$ value of 2. Successful treatments in poultry have been also reported. Nelson et al. (1971) added phytase produced by a culture of Aspergillus ficium to the diet of chickens and found an increase in bone ash content compared to control. KiISKInen and PIIRONEN (1990) showed improved plant-P digestibility in broilers after phytase supplementation.

In conclusion, the results of present study demonstrate that addition of a microbial phytate degrading enzyme in maize-soybean meal diet enhances the absorption of vegetable phosphorus and other essential minerals. More of the pigs' requirement for phosphorus could be met by $\mathrm{P}$ in maize and SBM if 
Table 6. Mineral excretion, apparent absorption and retention in pigs.

Exp. 2.

\begin{tabular}{|c|c|c|c|c|c|}
\hline Treatments & 1 & 2 & 3 & SEM & $\begin{array}{l}\text { Statis. } \\
\text { signif. }\end{array}$ \\
\hline \multicolumn{6}{|l|}{ Calcium } \\
\hline Intake, g/d & 15.91 & 15.60 & 15.84 & 0.131 & NS \\
\hline Excret. in faeces, g/d & $9.72^{\mathrm{a}}$ & $8.62^{\mathrm{ab}}$ & $7.64^{b}$ & 0.419 & $*$ \\
\hline Absorption & $0.388^{\mathrm{a}}$ & $0.450^{\mathrm{ab}}$ & $0.517^{\mathrm{b}}$ & 0.0248 & $*$ \\
\hline Excretion in urine, $\mathrm{g} / \mathrm{d}$ & $0.52^{\mathrm{a}}$ & $3.65^{\mathrm{b}}$ & $1.87^{\mathrm{c}}$ & 0.186 & $* * *$ \\
\hline Retention, g/d & $5.67^{\mathrm{a}}$ & $3.33^{\mathrm{b}}$ & $6.33^{a}$ & 0.426 & $* *$ \\
\hline of intake & $0.356^{\mathrm{a}}$ & $0.216^{\mathrm{b}}$ & $0.400^{\mathrm{a}}$ & 0.0287 & $* *$ \\
\hline of absorption & $0.922^{\mathrm{a}}$ & $0.466^{\mathrm{b}}$ & $0.775^{c}$ & 0.0328 & $* * *$ \\
\hline \multicolumn{6}{|l|}{ Magnesium } \\
\hline Intake, g/d & 3.48 & 3.47 & 3.52 & 0.029 & NS \\
\hline Excret. in faeces, $\mathrm{g} / \mathrm{d}$ & $2.53^{\mathrm{a}}$ & $2.17^{\mathrm{ab}}$ & $2.07^{b}$ & 0.089 & $*$ \\
\hline Absorption & $0.273^{\mathrm{a}}$ & $0.375^{b}$ & $0.412^{b}$ & 0.0243 & $* *$ \\
\hline Excretion in urine, $\mathrm{g} / \mathrm{d}$ & $0.42^{\mathrm{a}}$ & $0.74^{b}$ & $0.77^{\mathrm{b}}$ & 0.032 & $* * *$ \\
\hline Retention, g/d & 0.54 & 0.56 & 0.68 & 0.096 & NS \\
\hline of intake & 0.153 & 0.163 & 0.193 & 0.0282 & NS \\
\hline of absorption & 0.544 & 0.421 & 0.463 & 0.0481 & NS \\
\hline \multicolumn{6}{|l|}{ Iron } \\
\hline Intake, $\mathrm{mg} / \mathrm{d}$ & $561^{\mathrm{a}}$ & $338^{b}$ & $344^{b}$ & 3.4 & $* * *$ \\
\hline Excret. in faeces, mg/d & $408^{a}$ & $279^{b}$ & $280^{b}$ & 11.5 & $* * *$ \\
\hline Absorption & 0.272 & 0.177 & 0.184 & 0.0279 & NS \\
\hline Excretion in urine, $\mathrm{mg} / \mathrm{d}$ & $3.10^{\mathrm{a}}$ & $1.42^{\mathrm{b}}$ & $1.62^{b}$ & 0.301 & $* *$ \\
\hline Retention, mg/d & $150^{\mathrm{a}}$ & $58^{\mathrm{b}}$ & $62^{b}$ & 11.2 & $* * *$ \\
\hline of intake & 0.266 & 0.173 & 0.179 & 0.0276 & NS \\
\hline of absorption & 0.977 & 0.972 & 0.974 & 0.0038 & NS \\
\hline \multicolumn{6}{|l|}{ Copper } \\
\hline Intake, mg/d & 184 & 182 & 184 & 1.5 & NS \\
\hline Excret. in faeces, mg/d & $178^{\mathrm{a}}$ & $156^{\mathrm{b}}$ & $157^{a}$ & 5.7 & $*$ \\
\hline Absorption & $0.031^{\mathrm{a}}$ & $0.143^{\mathrm{ab}}$ & $0.145^{\mathrm{b}}$ & 0.0294 & * . \\
\hline Excretion in urine, $\mathrm{mg} / \mathrm{d}$ & 1.7 & 2.1 & 1.3 & 0.31 & NS \\
\hline Retention, mg/d & $4.3^{\mathrm{a}}$ & $23.4^{\mathrm{ab}}$ & $25.6^{\mathrm{b}}$ & 5.15 & $*$ \\
\hline of intake & $0.021^{\mathrm{a}}$ & $0.136^{\mathrm{ab}}$ & $0.138^{\mathrm{b}}$ & 0.0291 & $*$ \\
\hline of absorption & 0.816 & 0.903 & 0.943 & 0.0183 & NS \\
\hline Zinc & & & & & \\
\hline Intake, $\mathrm{mg} / \mathrm{d}$ & 189 & 187 & 190 & 1.6 & NS \\
\hline Excret. in faeces, $\mathrm{mg} / \mathrm{d}$ & $184^{\mathrm{a}}$ & $159^{b}$ & $155^{a}$ & 6.0 & $*$ \\
\hline Absorption & $0.019^{\mathrm{a}}$ & $0.150^{\mathrm{b}}$ & $0.181^{\mathrm{b}}$ & 0.0314 & $*$ \\
\hline Excretion in urine, $\mathrm{mg} / \mathrm{d}$ & 10.6 & 13.3 & 13.3 & 2.38 & NS \\
\hline Retention, mg/d & $-6.4^{a}$ & $14.4^{\mathrm{ab}}$ & $21.2^{\mathrm{b}}$ & 5.66 & $*$ \\
\hline of intake & $-0.038^{a}$ & $0.078^{\mathrm{ab}}$ & $0.111^{\mathrm{b}}$ & 0.0314 & $*$ \\
\hline of absorption & $1.467^{\mathrm{a}}$ & $0.416^{\mathrm{b}}$ & $0.531^{\mathrm{b}}$ & 0.2260 & $*$ \\
\hline
\end{tabular}

${ }^{a-c}:^{*} \mathrm{P}<0.05,{ }^{* *} \mathrm{P}<0.01,{ }^{* * *} \mathrm{P}<0.001$.

phosphorus could be converted to an available form. Phosphorus content in pig manure could be reduced followed the improved plant$\mathrm{P}$ utilization with the present phytase treatment of the feed. Accumulation of $\mathrm{P}$ in cultivated fields is increased by using manures with high $\mathrm{P}$ content. Whether the use of enzymatic treatment to release plant phosphorus is economically feasible compared to addition of other sources of phosphorus to feed remains to be determined.

Acknowledgements. The author is grateful to Ms. Ulla Roiha, M. Agr.Sc. and Mr. Juha Suomi for technical assistance and to Ms. Hilkka Siljander-Rasi, M. Agr.Sc. and Mr. Erkki Aimonen, M. Agr.Sc. for their valuable assistance in statistical analysis. The financial support to this study was received from Alko Ltd. 


\section{References}

ARC. 1981. The nutrient requirements of pigs. Agricultural Research council. 307 p.

BAgheri, S. \& Gueguen, L. 1985. Effect of wheat bran and pectin on the absorption and retention of phosphorus, calcium, magnesium and zinc by the growing pig. Reprod. Nutr. Develop. 25: 705-716.

Boyd, R.D., HAll, D. \& Wu, J.F. 1983. Plasma alkaline phosphatase as a criterion for determining availability of phosphorus for swine. J. Anim. Sci. 57: 396-401.

Calvert, C.C., Besecker, R.J., Plumlee, M.P., Cline, T.R. \& Forsyth, D.M. 1978. Apparent digestibility of phosphorus in barley and corn for growing swine. J. Anim. Sci. 47: 420-426.

Camire, A.L., Clydesdale, F.M. 1982. J. Food. Sci. 47: 575-578.

Cromwell, G.L. 1980. Biological availability of phosphorus in feedstuffs for swine. Feedstuffs 52 (9): $38-42$.

- 1989. Requirements, biological availability of calcium, phosphorus for swine evaluated. Feedstuffs 61: $16-25$.

— \& Stahly, T.S. \& Overfield, J.R. 1978. Effects of dried yeast on phosphorus utilization in pigs. J. Anim. Sci. 47 (Supp. 1): 78.

Frape, D.L., Wayman, B.J., Tuck, M.G. 1979. The utilization of phosphorus and in wheat offal by growing pigs. J. Agric. Sci. 93: 133-146.

Fourdin, A., Camus, P., Cayron, B., Colin, C. \& PoinTILLART, A. 1988. Improvement of the utilization of phytates in pigs by incorporation of products with a high phytase activity: rye and wheat bran. J. Recher. Porc. France 20: 327-331.

Hartog den L.A., Tol van der, J.J., Boer, H. \& Verste. GEN, M.W.A. 1988. Phosphorus digestibility of some inorganic $\mathrm{P}$-sources in pigs determined by quantitative collection of faeces and with a marker. Proc. 4th Intern. Sem. Digestive Physiology in Pigs. Polish Academy of Sciences, Jablonna 328-335.

Irwing, G.C.J. 1980. Phytates. Inositol phytates. Ed. Cosgrove, D.J. Amsterdam. Elsevier. p. 85-127.

Jongbloed, A.W. 1987. Phosphorus in the feeding of pigs. Effect of diet on the absorption and retention of phosphorus by growing pigs. I.V.V.O. Rep. No. 179. 343 p. Lelystad, The Netherlands.

Jorgensen, H., Just, A. \& Fernandes, J.A. 1985. The influence of dietary supply of minerals on apparent absorption and retention of minerals in growing pigs. Beretn. Statens Husdyrbr.forsog No 580: 360-363.

Kinsinen, T. \& Piironen, J. 1990. In print.

Nelson, T.S., Ferrara, L.W. \& Storer, N.L. 1969. Phytate phosphorus content of feed ingredients derived from plants. Poult. Sci. 47: 1372.

-, Shieh, R.R., Wodinski, R.J. \& WARE, J.H. 1971. Effect of supplemental phytase on the utilization of phytate phosphorus by chicks. J. Nutr. 101: 1289-1293.

OKSBJerg, N. 1988. Digestibility of total phosphorus and phytate phosphorus in cereals for growing pigs. Proc. 4th Intern. Sem. Digestive Physiology in Pigs. Polish Academy of Sciences, Jablonna. 352-356.

Pierce, A.B., Doige, C.E., Bell, J.M. \& Owen, B.D. 1977. Availability of phytate phosphorus to the growing pig receiving isonitrogenous diets based on wheat or corn. Can. J. Anim. Sci. 57: 573-583.

Pointillart, A. 1988. Phytate phosphorus utilization in growing pigs. Proc. 4th Intern. Sem. Digestive Physiology in Pigs. Polish Academy of Sciences, Jablonna. 319-326.

-, Fontane, N. \& Thomasset, M. 1984. Phytate phosphorus utilization and intestinal phosphatases in pigs fed low phosphorus: Wheat or corn diets. Nutr. Rep. Inter. 29: 473-483.

Salo, M-L., Tuori, M. \& KiISKinen, T. 1982. Rehutaulukot ja ruokintanormit.

Shurson, G.C., Ku, P.K. \& Miller, E.R. 1983. Evaluation of a yeast phytase product for improving phytate phosphorus bioavailability in swine diets. Mich. State Univ. Res. Rep. AS-SW - 8324.

TAYSSKY, H.H. \& SHORR, E. 1953. A microcolorimetric method for the determination of inorganic phosphorus. J. Biol. Chem. 202: 675-685.

Zhu, X.S., Seib, P.A., Allee, G.L. \& Liang, Y.T. 1990. Preparation of a low-phytate feed mixture and bioavailability of its phosphorus to chicks. Anim. Feed. Sci. Techn. 27: $341-351$.

Ms received november 6, 1990 
SELOSTUS

\section{Fytaasilisäyksen vaikutus kasviperäisen fosforin hyväksikäyttöön \\ lihasian ruokinnassa}

\section{Matti Näsi}

Helsingin yliopisto, kotieläintieteen laitos

Kahdessa sulavuus- ja tasekokeessa tutkittiin bioteknisesti tuotetun sienifytaasin tehoa kasviperäisen fytiinifosforin hyvăksikäytön parantamiseen lihasikojen ruokinnassa. Maissi-soijarouhedieetin fosforin sulavuus oli alhainen, $0.16-0.23$, ja se oli merkitsevästi alempi kuin fosfaatilla täydennetyn dieetin P:n sulavuus (0.42). Fytaasilisăys paransi merkitsevästi kasviperäisen fosforin sulavuutta $(0.40-0.28)$. Fosforin pidättyminen lisääntyi myös merkitsevăsti fytaasikăsittelyn ansiosta. Samoin kal- siumin sulavuutta ja pidăttymistă voitiin parantaa fytaasilisäyksen avulla. Rehujen fytiinifosforin hyvăksikãyttöä voitiin parantaa huomattavasti fytaasilisăyksellă ja samalla saada aikaan sonnan fosforipitoisuuden alenemista. Fosfaattien käyttőă voitaisiin ilmeisesti vähentäă sikojen ruokinnassa lisaaämällă orgaanisen fosforin käyttökelpoisuutta ja siten vähentää lannan mukana poistuvan fosforin määräă. 